\title{
Domestication strategy in rendering lexical and phraseological units in American university discourse: Stylistic aspects
}

\author{
Viktoriia Masanovets ${ }^{1}$ \\ ${ }^{1}$ Taras Shevchenko National University of Kyiv, Department of Theory and Practice of Translation \\ from English, Taras Shevchenko Boulevard, 14, Kyiv Ukraine
}

\begin{abstract}
The article aims at disclosing stylistic aspects of the domestication strategy representation and establishing correlations between domestication translation strategy and ways of English-Ukrainian translation of lexical and phraseological units in American university discourse based on the novel The Secret History by Donna Tartt and its Ukrainian translation by Bohdan Stasiuk. A comparative, stylistic, contextual and translation analyses of the source and target texts were employed. The research argues that in order to minimise the number of foreign elements in the target text, to make it more comprehensible for the reader the notion of domestication is applied in the translation. The study singles out six groups of lexical and phraseological units in the ST domesticated in the Ukrainian translation (idioms, phrasal verbs, colloquial vocabulary (slang and vulgarisms), interjections, proper nouns and stylistically neutral vocabulary) and means of their domestication in the TT (translation by means of stylistic equivalents, stylistic translation transformations of expressivation and logisation). According to the obtained results, the prevailing ways of representation of domestication strategy in the Ukrainian translation of American university discourse are translation by means of stylistic equivalents predominantly used for reproducing ST idioms, phrasal verbs, interjection, colloquial vocabulary and domesticated proper nouns; stylistic translation transformation of expressivation (applied to stylistically neutral ST vocabulary) and logisation (several phraseological units).
\end{abstract}

\section{Introduction}

Literary translation is a challenging activity which involves a great amount of creativity. Works of literature are embedded in the culture of the nation and, as a rule, targeted at representatives of the culture. Literature is not just about giving information - it brings out emotions, imparts values and creates an imprint of the people's way of living. Thus, translators of a literary work do not only transfer the information expressed by one language to another, but also recreate the whole range of functions. A translated work of art

\footnotetext{
${ }^{1}$ Corresponding author: vitamasanovec@gmail.com
} 
finds its place in the target culture, and over the centuries scholars have been preoccupied with the question of how much of the source culture it should contain.

Domestication and foreignisation are the two strategies advocated by Lawrence Venuti for translating cultural elements. Domestication is defined in translation studies as a translation strategy in which a transparent, fluent style is adopted in order to minimize the strangeness of the foreign text for the target language reader [1]. This means that the translator eliminates puzzling concepts, making it more accessible to the reader, and the translated source text reads more fluently. The translator becomes "invisible" and the target text (TT - hereafter) offers the impression as if it were created in the target language [1]. Foreignisation, on the other hand, means that a TT deliberately breaks target conventions by retaining something of the foreignness of the original.

It is worth mentioning that Venuti himself favours foreignisation and supports that by arguing that a translator's mission is to retain the cultural values of the source language and not manipulate it into the target language. Before that, scholars such as Eugene Nida had strongly argued for the opposite strategy. Nida stresses that a successful translation is created when the target text meets the cultural expectations of the receivers, and this can be achieved by minimizing the foreignness and strangeness of the origin text [2].

One way or another, the translator decides on the overall translation strategy taking into consideration many factors, and the specific features of the source text (ST - hereafter) are one of them. Literary text can combine features of different discourses, depending on the reality it describes. Currently, there is no clear and universally accepted definition of the notion of discourse. Since it is the object of investigation of various sciences (philosophy, psychology, political science, linguistics, etc.), its interpretation that would cover all aspects of its existence is absent. Instead, each science offers its own definition. One of the most common definitions of discourse is its formulation by N. Arutyunova as a speech immersed in life [3]. Discourse is a text (speech event) in combination with extralinguistic - pragmatic, social, cultural, psychological - factors [3]. While analysing discourse, linguists concentrate on the problems of the relation between the concepts of discourse and text, discourse and functional style, discourse and dialogue, trying to provide the main characteristics of different types of discourse. Taking into account the existing definitions of discourse and the specifics of the material of our study, we interpret university discourse as texts with specific formal and semantic features that reflect social reality in the context of the university [4].

The novel The Secret History (Donna Tartt, 1992) [5] and its Ukrainian (Bohdan Stasiuk, 2017) translation [6] are in the focus of the present research. It is a campus novel that reflect social reality in the context of an elite liberal arts college located in Vermont which makes it a literary embodiment of American university discourse. The novel tells the story of a closely knit group of six Classics students narrated by Richard Papen - one of the students - who reflects years later upon the situation that led to the murder of their friend Bunny. Academically and socially isolated group of friends talk about works of literature, Greek philosophy and history, have parties and drink alcohol. The language of the novel is rich in bookish vocabulary, inclusions of foreign words of Latin and Greek origin and informal words.

The language of the Ukrainian translation of the novel done by Bohdan Stasiuk is rich and racy. There are many culture-specific phraseological units, slang and informal words which help to reproduce multifaceted stylistic nature of American university discourse. Some of the said units are used in the TT to reproduce stylistically neutral words from the ST. The translator employs stylistic transformations to implement the domestication strategy and to bring the translated text closer to the reader.

The aim of the research is to disclose stylistic aspects of the domestication strategy representation and to establish correlations between domestication translation strategy and 
ways of English-Ukrainian translation of lexical and phraseological units in American university discourse based on the novel The Secret History by Donna Tartt and its Ukrainian translation by Bohdan Stasiuk. To achieve the aim, the following objectives were set:

- $\quad$ to specify the notions of domestication strategy;

- to analyse lexical and phraseological units from the ST that were domesticated in the TT; to identify ways of their domestication;

- to research the correlation between domestication strategy and stylistic transformations as well as translation with stylistic equivalents in rendering various lexical and phraseological units in American university discourse.

\section{Theoretical Background}

The notion of "translation strategy" appeared long before the emergence of translation studies as an academic discipline. H. Krings defines translation strategy as "translator's potentially conscious plans for solving concrete translation problems in the framework of a concrete translation task" [7, p. 264]. W. Loescher defines translation strategy as "a potentially conscious procedure for solving a problem faced in translating a text, or any segment of it" [8, p. 8]. R. Bell differentiates between global (those dealing with whole texts) and local (those dealing with text segments) strategies and confirms that this distinction results from various kinds of translation problems [9, p. 188]. In our research we follow Venuti who indicates that translation strategies "involve the basic tasks of choosing the foreign text to be translated and developing a method to translate it" and employs the concepts of domesticating and foreignising to refer to translation strategies [1, p. 240].

According to Venuti, domestication refers to an ethnocentric reduction of the foreign text to target-language cultural values, which brings the author back home, while foreignisation is an ethnodeviant pressure on cultural values to register the linguistic and cultural difference of the foreign text, sending the reader abroad [1, p. 20]. Generally speaking, domestication designates the type of translation in which a transparent, fluent style is adopted to minimise the strangeness of the foreign text for target language readers, while foreignisation means a target text is produced which deliberately breaks target conventions by retaining something of the foreignness of the original [10].

Disputes over domestication and foreignisation have existed for a long time. The wild variety of viewpoints presented to be for or against domestication or foreignisation are from different perspectives. Both domestication and foreignisation have their advantages and disadvantages. Venuti himself is an advocate of foreignisation, since he believes that there is violence residing in the very purpose and activity of domestication which involves an ethnocentric reduction of the foreign text to target-language cultural values. Venuti proposes foreignisation, which preserves the ST formal features and in turn informs the readers of the SL-culture, as the strategy of resistant translation against the tradition of smooth translation [1, p. 242].

Domesticated translation is easier for the readers to understand and accept due to its naturalness and smoothness. These particular characteristic features of the domesticated text can be achieved through various translation techniques. Many scholars such as V. Vinogradov [11], V. Komissarov [12], Y. Retsker [13], E. Nida [14], P. Newmark [15], and others studied the problems of translation strategies, methods, and ways of translation that correlate with specific strategies. In this research we tried to show the correlation between domestication translation strategy and translation by means of stylistic equivalents, as well as stylistic transformations of expressivation and logisation used for the purpose of implementing the strategy. 
Translation transformations are any kinds of changes, necessary for adequate translation, caused by lexical, grammatical, and cultural differences between languages and nations $[16$, p. 7]. Ukrainian and foreign scholars single out several classifications of translation transformations, but generally they are divided into lexical, grammatical and stylistic transformations $[2,17,18]$.

According to Naumenko and Gordyeyeva, stylistic transformations are ways of translation in which the translator shifts stylistic stresses, neutralising or, conversely, actualising connotative shades of meaning, or adapting the language of translation to the stylistic norms adopted in the TL [18]. Stylistic translation transformations include: logisation, expressivation, modernisation and archaisation, and can be explained by the following procedures:

1. Logisation: an emotionally and expressively marked or ethnically marked unit in the SL is replaced by its stylistically neutral equivalent in the TL, which eliminates or weakens the aesthetic function of the original.

2. Expressivation: a stylistically neutral unit in the SL is replaced by its stylistically marked equivalent in the TL, which gives the translation an emotionally expressive colouring.

3. Modernisation: obsolete, archaic words and expressions are rendered by means of their modern equivalents, which weakens the aesthetic function of the original.

4. Archaisation: modern common vocabulary is translated with outdated, archaic words and expressions to give the language of translation the necessary stylistic colouring.

In some cases, the fluency of the TT is obtained by means of stylistic equivalents, when no stylistic translation transformations are applied but a stylistically marked lexical or phraseological unit is used in the TT to reproduce a stylistically marked lexical or phraseological unit in the ST. By "stylistic equivalents" we mean phraseological or lexical units with the same or similar stylistic load which have the same or similar stylistic effect in the given context within the specific discourse.

In fulfilling the objectives of the study, a comparative analysis complemented by contextual, stylistic and translation analyses were applied. The main general methods of the research include induction, deduction, classification method, the method of quantitative estimate, and the continuous sampling method. The research has been conducted in several stages. At the first stage, by way of the continuous sampling method, we collected the material of our research and worked out the research methodology. At the second stage, domesticated lexical and phraseological units in the TT and ST were analysed and categorised. At this stage, contextual, stylistic and translation analyses were used in the research to determine lexical and phraseological groups domesticated in translation and ways of their translation, including stylistic translation transformations. At the final stage of our research, we employed translation analysis of the original text and its translation into Ukrainian, as well as method of quantitative estimate to describe the research results and establish the correlation between the ways of translation and domestication strategy in the TT.

\section{Research Results and Discussion}

The Secret History by Donna Tartt is an inverted detective story shaped in a form of a campus novel - genre which in its current form dates back to the early 1950s [19]. A campus novel, also known as an academic novel, is a novel whose main action is set in and around the campus of a university. As a rule, it can be characterized by the following elements: a finite, enclosed space, like a boarding school or like Agatha Christie's countryhouses (the campus murder mystery being its own respectable sub-genre); academic terms, usefully, begin and end; clear power relationships (teacher/student; tenured 
professor/scrabbling lecturer), etc. [20]. Tartt's debut has everything: snotty classics students, alluring and mysterious professors, convoluted social hierarchies, murder, Bacchic rites, class warfare, allusions to the ancients, and some of the most intelligent, gorgeous writing going.

According to Kukharenko, the English word-stock can be divided into three uneven groups, differing from each other by the sphere of its possible use. The biggest division is made up of neutral words, possessing no stylistic connotation and suitable for any communicative situation, two smaller ones are literary (including general literary vocabulary and special groups of terms and archaisms) and colloquial (including general colloquial vocabulary and special groups of slang, argonisms, vulgarisms and dialectal words) strata respectively. The characteristic features of the American university discourse on lexical level stem from the main themes of the campus novel genre and include a wide range of literary vocabulary (e.g., milieu, distasteful, peremptory, beguilingly, demur, diatribe, etc.) and colloquial vocabulary, including slang and vulgarisms (e.g., gal, pot, stoned, damned, etc.) [21]. This stylistic diversity of lexical units makes stylistic contrast a distinctive feature of American university discourse.

Table 1 shows a vivid example of the said stylistic contrast.

Table 1. Stylistic contrast in American university discourse: neutral, literary, colloquial strata of vocabulary.

\begin{tabular}{|c|c|}
\hline Eng. (Tartt, 1992) [5] & Ukr. (Tartt, 2017) [6] \\
\hline $\begin{array}{l}\text { Bunny had been talking the night } \\
\text { before about how he wanted eight children, } \\
\text { four boys and four girls; which had } \\
\text { prompted a long, humorless speech from } \\
\text { Henry about how the fulfillment of the } \\
\text { reproductive cycle was, in nature, an } \\
\text { invariable harbinger of swift decline and } \\
\text { death. } \\
\text { 'It's terrible,' said Charles. 'Really, I } \\
\text { can just see him. Standing out in a } \\
\text { yard wearing some kind of stupid apron.' } \\
\text { 'Cooking hamburgers on the grill.' } \\
\text { 'And about twenty kids running around him } \\
\text { and screaming.' }\end{array}$ & $\begin{array}{l}\text { Минулої ночі Банні розводився про те, щуо } \\
\text { він хоче мати восьмеро дітей, четверо } \\
\text { хлопиів і четверо дівчат. Це спровокувало } \\
\text { Генрі на тривалу невеселу тираду про те, } \\
\text { як реалізація репродуктивного циклу за } \\
\text { своєю природою є неминучою предтечею } \\
\text { швидкого занепаду й смерті. } \\
\text { - Просто жах, - кивнув Чарльз. -Я } \\
\text { так і бачу його. У дворі. Він начепив } \\
\text { якийсь дебільний фартух. } \\
\text { - Смажить гамбургери на тратиі. } \\
\text { - А щзось із два десятки гавриків гасає } \\
\text { навколо й верещить. }\end{array}$ \\
\hline
\end{tabular}

The excerpt contains words of all three strata: neutral (night, see, scream, etc. naturally, the biggest one), literary (decline, harbinger, reproductive cycle) and colloquial (stupid, kids) [22]. Ukrainian translation conveys the stylistic contrast by means of corresponding stylistically marked words (literary репродуктивний ичикл, предтеча занепаду are intertwined with дебільний, гаврики) [23]. Moreover, the TT has even deeper stylistic contrast, since the translator uses stylistic transformation of expressivation replacing stylistically neutral words (talking, speech, wearing, running, screaming) [22] with colloquial words (розводитись, начепити, дебільний, гаврики, гасати, верещати) [23]. The use of colloquial vocabulary enhances the expressiveness of the TT and make the conversation between the characters sound more natural.

In the following example, philosophers' names are mixed up with colloquial vocabulary. The scene is set in a classroom where the group of friends are waiting for their professor. Richard Papen (the protagonist and narrator of the story) feels anxious - he is a newcomer here. His groupmates are asking him questions about works he reads and authors he likes. Trying to pass for an erudite and to fit in, Richard lies that he reads Plotinus, but to his horror he can't recall any of Plotinus' works: 
Table 2. Stylistic contrast in American university discourse: proper nouns from the area of philosophy and colloquial vocabulary.

\begin{tabular}{|l|l|}
\hline \multicolumn{1}{|c|}{ Eng. (Tartt, 1992) [5] } & \multicolumn{1}{|c|}{ Ukr. (Tartt, 2017) [6] } \\
\hline Unfortunately my mind went blank, and I & На жаль, у голові тільки вітер гудів. Я не \\
could not think of a single thing I knew for & міг пригадати жодної речі, шо абсолютно \\
sure Plotinus had written. The Eclogues"! & точно належала би Плотіну. «Еклоги»? \\
No, dammit, that was Virgil. & Ні, хай йому грець, то ж Вергілій. \\
\hline
\end{tabular}

In the ST, the proper names of Plotinus, The Eclogues and Virgil neighbour an expressive interjection dammit and idiom go blank, which creates a humorous effect. The translator resorts to domestication strategy and uses racy Ukrainian stylistic equivalents вітер гуде and хай иому грець, thus, successfully coping with the task of preserving the humorous effect.

It is worth mentioning that the translator applies both foreignisation and domestication translation strategies in his work. Foreignisation can be seen in translation of proper nouns rendered by means of transcoding or remained in its original form (Richard Papen Річард Пейпен, Непry - Генрі, готельчик Holiday Inn, бісквіти Twinkiе та шоколадні тістечка Но Ноs, журнал Life, мелений Folgers), foreign language inclusions explained in footnotes (Вони здавалися величними створіннями з такими очима, такими руками, такими поглядами - sic oculos, sic ille manus, sic oraferebat), etc. It can be a subjectmatter of further research, but in this article we want to focus on domestication in the translated version of the novel and ways of its implementation.

By means of continuous sampling method, 191 domesticated lexical and phraseological units from the TT were chosen and compared with the corresponding lexical and phraseological units in the ST. As a result, six groups of lexical and phraseological units in the ST domesticated in the Ukrainian translation were singled out, namely: (1) idioms -26 units (14\%); (2) phrasal verbs - 21 units (11\%); (3) colloquial vocabulary (slang and vulgarisms) - 39 units (20\%); (4) interjections - 18 units (9\%); (5) proper nouns - 3 units $(\mathbf{2 \%})$; (6) stylistically neutral vocabulary -84 units $(\mathbf{4 4 \%})$, which creates the following percentage correlation (Fig. 1):

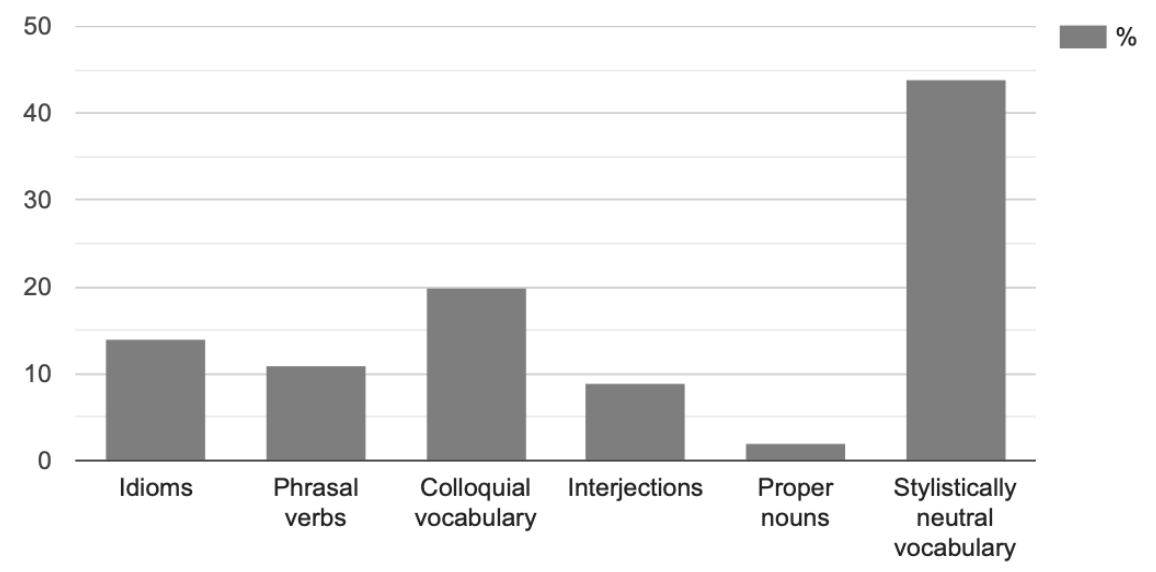

Fig. 1. Percentage correlation of phraseological and lexical units domesticated in the TT.

Lexical and phraseological units from all groups underwent stylistic transformations of expressivation and logisation in translation or were rendered by Ukrainian equivalents. As the research has shown, one of the mentioned ways of translation (stylistic transformations or translation with a stylistic equivalent) prevails in each group of domesticated lexical units. For example, 21 out of 26 English idioms were reproduced by stylistic equivalents, 5 
idioms - through the translation transformation of logisation. The following analysis of the material provides a detailed picture of how each lexical and phraseological group was domesticated in the Ukrainian translation and which ways of translation, including stylistic transformations, were applied.

\subsection{Idioms}

Idioms are generally defined as language-specific expressions which usually carry a nonliteral meaning that can be very different from the literal meaning of the expression. Idiomatic expressions are common in all languages and they are used widely in all sorts of communication; in written as well as in spoken interaction, in formal and informal contexts. Idioms are colourful and lively expressions which are usually unique and specific to a particular language [24].

We have analysed 26 English idioms and their counterparts in the Ukrainian translation. The comparative analysis complemented by contextual, stylistic and translation analyses showed that translation with stylistic equivalents ( 21 out of 26 or $81 \%$ ) prevails. However, a stylistic equivalent is not equal to a phraseological equivalent. According to Zarytskyi, there are six ways of rendering phraseological units into TL, namely, by means of: (a) phraseological equivalents; (b) partial equivalents; (c) phraseological analogues; (d) contextual equivalents; (e) calque translation; (f) description [25]. The following examples illustrate how partial and contextual equivalents, phraseological analogues and idioms rendered by means of descriptive translation can function as stylistic equivalents within the framework of American university discourse.

Table 3 shows the examples of partial equivalents:

Table 3. Idioms rendered by means of partial equivalents.

\begin{tabular}{|c|l|l|}
\hline & \multicolumn{1}{|c|}{ Eng. (Tartt, 1992) [5] } & \multicolumn{1}{|c|}{ Ukr. (Tartt, 2017) [6] } \\
\hline 1 & $\begin{array}{l}\text {...he always knew the right nerve to } \\
\text { touch }\end{array}$ & $\begin{array}{l}\text {..він завжди знав, яку струну } \\
\text { зачепити. }\end{array}$ \\
\hline 2 & $\begin{array}{l}\text { This is serious business and if you want } \\
\text { my two cents }\end{array}$ & $\begin{array}{l}\text { Це дуже серйозна справа, і якщо в мене } \\
\text { вже з'явилася нагода вставити свої } \\
\text { n'ять центів }\end{array}$ \\
\hline 3 & in the dead of night & глупої ночі \\
\hline
\end{tabular}

Partial equivalents manage to convey informal nature of the original, even though the corresponding phraseological units in the ST and TT are not complete phraseological equivalents. A phraseological unit вставити свої n'ять центів follows the pattern of the Ukrainian colloquial phraseological expression вставити свої п'ять копійок, but in this particular case the translator combines both translation strategies, foreignising one word cents - and domesticating the whole syntactic structure. Despite the foreignness of the word иентів, the whole translated sentence sounds natural and fluent, following one of the characteristics of domesticated texts mentioned by Venuti, due to the use of the phraseological unit pattern вставити (встромити) свої п'ять (три) копійок (копійки) well-known to an average Ukrainian-speaking reader [26].

Examples of the descriptive translation of English idioms by means of stylistic equivalents are given in Table 4:

Table 4 Idioms rendered by means of descriptive translation.

\begin{tabular}{|c|l|l|}
\hline & \multicolumn{1}{|c|}{ Eng. (Tartt, 1992) [5] } & \multicolumn{1}{c|}{ Ukr. (Tartt, 2017) [6] } \\
\hline 1 & ...they were giving him the same line & ...вони наплели того самого \\
\hline 2 & Francis frequently made fun of me & Френсіс часто киив з мене \\
\hline 3 & 'Yои look like you could use a drink, & Слухай, у тебе геть хріновий вигляд. \\
\hline
\end{tabular}




\begin{tabular}{|l|l|l|}
\hline & man & Tобі треба бахнути \\
\hline
\end{tabular}

Sentences from this group of domesticated items have informal stylistic colouring as well. The main stylistic purpose of the used idiomatic expressions in the ST is to reproduce informality of the characters' speech. For this reason, it is possible to argue that the colloquial lexical units in the TT serve as stylistic equivalents of the English idiomatic expression, since they render the informality of the English text on lexical level: to give someone a line means to lead someone on; to deceive someone with false talk наплітати перен., розм. Наговорити багато неправди, брехні, чого-небудь безглуздого. As one can see, the dictionaries give similar definitions of the units, both informal. In the third example, the idiomatic expression (one) could use (something) means one needs something; one would be or feel better if one had something. The translated version of the sentence does not have a phraseological equivalent, but it contains two lexical units added by the translator: a stylistically informal adjective хріновий and a verb бахнути. The adjective хріновий is a slang word used in this context to describe the state of the character and, thus, to render the meaning of the idiom though sense development: the character could use a drink, which means he would feel better if he had a drink because he looks bad [22,23]. Readers of the ST get the idea of the character's state from the idiom's shades of meaning, while for Ukrainian readers it explained by two additional informal lexical units. The informal style of these units helps to reproduce the informality of the conversation between young people which gets lost in stylistically neutral translation.

English idioms given in Table 5 are reproduced in the Ukrainian version of the novel by means of descriptive translation as well. The main difference from the previously analysed group of phraseological units is that the translator applies the stylistic transformation of logisation replacing stylistically marked units with stylistically neutral ones:

Table 5. Idioms rendered by means of stylistic transformation of logisation.

\begin{tabular}{|c|l|l|}
\hline & \multicolumn{1}{|c|}{ Eng. (Tartt, 1992) [5] } & \multicolumn{1}{c|}{ Ukr. (Tartt, 2017) [6] } \\
\hline 1 & Actually, this rang a bell. & Я й справді когось такого пригадував. \\
\hline 2 & This'd hit the spot about now & Te, щио треба саме зараз. \\
\hline 3 & $\begin{array}{l}\text { Because he knew I kept late hours, toо, } \\
\text { Henry would sometimes stop by... }\end{array}$ & $\begin{array}{l}\text { Так, Генрі знав, щзо я також працююо } \\
\text { допізна, а тому інколи зайжджав до } \\
\text { мене... }\end{array}$ \\
\hline 4 & Henry's going to have a ball with this & Генрі й сам нівроку повеселиться \\
\hline
\end{tabular}

The following examples (Table 6) are contextual equivalents, according to the classification of Zarytskyi [25]. Both Ukrainian phraseological units have the same meaning due to the context in which they are used.

Table 6. Idioms rendered by means of contextual equivalents.

\begin{tabular}{|c|l|lr|}
\hline & \multicolumn{1}{|c|}{ Eng. (Tartt, 1992) [5] } & \multicolumn{1}{|c|}{ Ukr. (Tartt, 2017) [6] } \\
\hline 1 & hit the mark harder than I'd thought. & $\begin{array}{l}\text { зіграли роль краще, ніж } \\
\text { розраховував. }\end{array}$ \\
\hline 2 & my mind went blank & уголові тільки вітер гудів & \\
\hline
\end{tabular}

Phraseological analogues are interlingual phraseological equivalents that are the same in content, stylistic characteristics, but different in lexical content and grammatical structure [25]. The following English idioms (Table 7) are rendered by means of corresponding Ukrainian stylistically informal phraseological units which function as phraseological analogues and stylistic equivalents due to their informal nature:

Table 7. Idioms rendered by means of phraseological analogues. 


\begin{tabular}{|l|l|l|}
\hline & \multicolumn{1}{|c|}{ Eng. (Tartt, 1992) [5] } & \multicolumn{1}{c|}{ Ukr. (Tartt, 2017) [6] } \\
\hline 1 & Bats in the belfry & Клепки всі погубив \\
\hline 2 & lock, stock and barrel & з усім гамузом \\
\hline 3 & speak of the Devil & про вовка промовка \\
\hline 4 & got completely rucked up. & упився як квач \\
\hline 5 & оut of the blue & як грім із ясного неба \\
\hline
\end{tabular}

The analysis of 26 English idioms and the corresponding units in the Ukrainian translation shows that in most cases Stasiuk uses stylistic equivalents (81\%), namely: partial equivalents (4 items), phraseological analogues (9 items), contextual equivalents (2 items) and descriptive translation (6 items) to preserve the stylistic colouring of the original, and to domesticate the ST. This way of translating idioms prevails in the novel as compared to stylistic transformation of logisation (5 items or approx. 19\%):

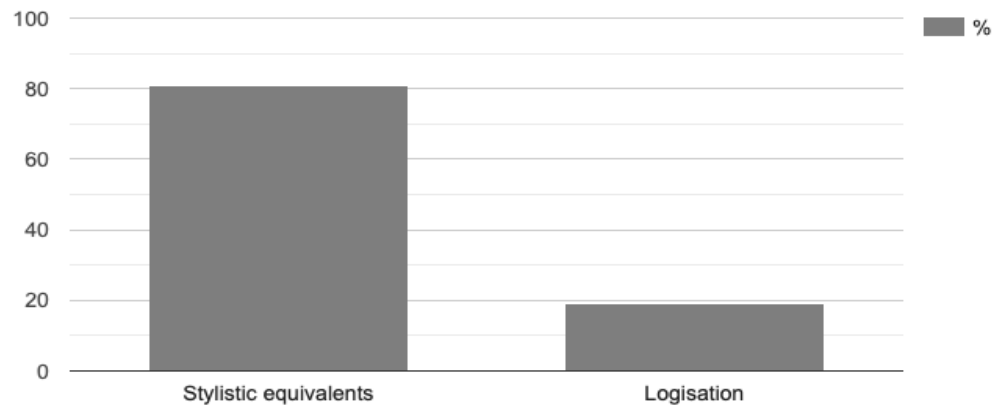

Fig. 2. Percentage correlation of ways of rendering ST idioms into the TT.

\subsection{Phrasal verbs}

Phrasal verbs, that is lexemes like to fling out "to rush (e.g., out of the room)", to throw out "to exclude, to degrade, to expel", consisting of a monolexemic verb and a second postpositive component of the complex adverbial and prepositional nature, represent one of the major peculiarities of verbal word building in Modern English [27]. Phrasal verbs are difficult to translate because the meaning of many expressions cannot be inferred from the words themselves. Many phrasal verbs have multiple meanings and one has to rely on the context to understand them.

We have analysed 21 phrasal verbs from the ST which were domesticated in the Ukrainian translation by means of Ukrainian informal vocabulary. The analysed English phrasal verbs are informal as well (e.g. shut up - (informal) to stop talking (often used as an order as a rude way of telling somebody to stop talking); mess somebody up - (informal) to cause somebody to have serious emotional or mental problems; freeze somebody out (informal) to be deliberately unfriendly to somebody, creating difficulties, etc. in order to stop or discourage them from doing something or taking part in something; stop by - to make a short visit somewhere, etc.) [28]. Thus, in order to preserve the informal style and to domesticate the text, Stasiuk chooses corresponding stylistically marked Ukrainian lexical units:

Table 8. Translation of English phrasal verbs by means of stylistically marked lexical units.

\begin{tabular}{|c|c|c|}
\hline & Eng. (Tartt, 1992) [5] & Ukr. (Tartt, 2017) [6] \\
\hline 1 & $\begin{array}{l}\text { I had frozen them out, a trick I'd } \\
\text { learned from Henry (no expression, } \\
\text { pitiless gaze, forcing intruder to retreat }\end{array}$ & $\begin{array}{l}\text { Я відкараскувався від них завдяки } \\
\text { трюку, якому навчився в Генрі: } \\
\text { безжалісний погляд та нуль емочй }\end{array}$ \\
\hline
\end{tabular}




\begin{tabular}{|c|c|c|}
\hline & in embarrassment) & $\begin{array}{l}\text { змушували ласих до подробиць } \\
\text { зніяковіло шезати }\end{array}$ \\
\hline 2 & bby. & Ой, та закрийся, Боббі. \\
\hline 3 & $\begin{array}{l}\text { But now I realized she was trying to } \\
\text { pick me up. }\end{array}$ & $\begin{array}{l}\text { Зате зараз, усвідомив я, вона } \\
\text { намагалася мене заарканити. }\end{array}$ \\
\hline 4 & at Laura is freaking out, okay & $\begin{array}{l}\text { Просто Лора з ума сходить, } \\
\text { кумекаєш? }\end{array}$ \\
\hline 5 & $\begin{array}{l}\text { hat because she ki } \\
\text { time }\end{array}$ & $\begin{array}{l}\text { Ти так говориш, бо вона постійно до } \\
\text { тебе підлизується }\end{array}$ \\
\hline
\end{tabular}

The informal phrasal verb freeze somebody out and kiss up to somebody are reproduced with informal verbs відкараскуватися - colloquial, to get rid of someone or something unpleasant; get out and підлизуватися - derogatory, to flatter with a useful purpose; shut up and pick up - with slang закрийся and заарканити [22, 23, 28]. An informal phraseological unit сходити з ума is used to reproduce the phrasal verb freak out. As we can see, different lexical and phraseological units employed for the translation of phrasal verbs share one common characteristic - informality. For this reason, they can serve as stylistic equivalents of the said phrasal verbs. TT does not increase or decrease the expressiveness of the original, but simply conveys the stylistic load of the ST.

\subsection{Colloquial vocabulary (slang and vulgarisms)}

As it has been mentioned, American university discourse is characterised by stylistic contrast due to different aspects of students' life described in the American campus novel. The Secret History contains a great number of slang and obscene words used mainly in dialogues. We have analysed 39 informal units in the ST which were domesticated in the TT and arrived at the conclusion that all of them were translated by means of stylistic equivalents (informal vocabulary, slang and obscene words, colloquial phraseological units). Some examples are shown in Table 9 below:

Table 9. English colloquial vocabulary translated by means of stylistic equivalents.

\begin{tabular}{|c|c|c|}
\hline & Eng. (Tartt, 1992) [5] & Ukr. (Tartt, 2017) [6] \\
\hline 1 & $\begin{array}{l}\text { 'You don't care about a goddamn } \\
\text { thing, do you? }\end{array}$ & Чорт, тобі жс усе пофіг, правда? \\
\hline 2 & ...after all that shit & Після отоїхерні \\
\hline 3 & $\begin{array}{l}\text { He looked really stoned. (...) } \\
\text { They all looked really stoned. }\end{array}$ & $\begin{array}{l}\text {...Клоук, який мав реально обдовбаний } \\
\text { вигляд (...) Вони всі виглядали дуже } \\
\text { накуреними. }\end{array}$ \\
\hline 4 & No, dammit, that was Virgil. & Hi, хай йому грець, то ж Вертілій. \\
\hline 5 & $\begin{array}{l}\text {...he got pretty flipped out by the whole } \\
\text { thing }\end{array}$ & $\begin{array}{l}\text {..від изих справ у н нього со стріха } \\
\text { посунулася. }\end{array}$ \\
\hline
\end{tabular}

The translator chooses a stylistic equivalent considering the SL items' shades of meaning and the context in which it is used. One stylistically marked lexical item can be translated with different stylistic synonyms. In the examples in Table 10 the same adjective/adverb fucking - a swear word that many people find offensive that is used to emphasize a comment or an angry statement [28] - is translated in five different ways:

Table 10. Different ways of translating the adjective/adverb fucking.

\begin{tabular}{|c|c|cccc|}
\hline & Eng. (Tartt, 1992) [5] & \multicolumn{4}{|c|}{ Ukr. (Tartt, 2017) [6] } \\
\hline 1 & 'You don't have a clue,' he said. His & y & нього очі & налилися кров'ю & uे \\
\hline
\end{tabular}




\begin{tabular}{|c|c|c|}
\hline & $\begin{array}{l}\text { eyes were bloodshot, uncomfortably } \\
\text { bright. 'Boy. You don't have a fucking } \\
\text { clue.' }\end{array}$ & $\begin{array}{l}\text { неприємно блищали. - Капещь, ти ж, } \\
\text { блядь, нічого не розумієш. }\end{array}$ \\
\hline 2 & $\begin{array}{l}\text {..Jesus, open them up and there's a } \\
\text { fucking Tintoretto on the inside. }\end{array}$ & $\begin{array}{l}\text { Господи, ти його розгортаєш, а звідти } \\
\text { на тебе дивиться грьобаний } \\
\text { Тінторетто. }\end{array}$ \\
\hline 3 & $\begin{array}{l}\text { 'I said I'm not fucking hungry,' said } \\
\text { Charles without looking up. }\end{array}$ & $\begin{array}{l}\text { Я ж, бляха-муха, сказав вам, щео не } \\
\text { голодний, - не піднімаючи погляду, } \\
\text { повторив Чарльз. }\end{array}$ \\
\hline 4 & $\begin{array}{l}\text { I don't have time to do anything with it. } \\
\text { I'm too busy sewing those damned } \\
\text { costumes for fucking As You Like It. }\end{array}$ & $\begin{array}{l}\text { Все одно часу немає щось із ним } \\
\text { робити. У мене повно крою та шиття } \\
\text { костюмів до гадського "Як вам ие } \\
\text { сподобається» }\end{array}$ \\
\hline
\end{tabular}

Since the adjective/adverb fucking has a very wide expressive range in the English language, the translator chooses an equivalent which is appropriate in the given context. The most expressive Ukrainian equivalents are used in emotionally charged scenes. In the first example, the character's eyes are bloodshot and uncomfortably bright - he is furious. He does not mince words and it is conveyed in the Ukrainian translation by means of an obscene lexical unit блядь [24]. In other sentences, which were taken from moderately calm conversations between characters, expressive but euphemistic lexical units are used.

\subsection{Proper nouns}

The Oxford Advanced Learner's Dictionary defines a proper noun (or proper name) as "a word that is the name of a person, a place, an institution, etc. and is written with a capital letter" [28]. Behnaz Sanaty Pour stated that a proper noun has these distinctive features in English: 1) it will be capitalized, no matter where it occurs in a sentence; 2) a proper name is a mono-referential name, i.e., it refers to a particular person, thing, or place; 3) It is not regularly preceded by a definite or indefinite article; 4) it is not used with limiting modifiers [29].

Most proper nouns in the novel are translated by means of transcoding (Richard Papen - Річард Пейпен, Francis - Френсіс, Camilla - Камілла, Buпnу - Банні еtc.). Although, several proper nouns used informally as nicknames were domesticated:

Table 11. Translation of proper nouns by means of stylistic equivalents.

\begin{tabular}{|l|l|l|}
\hline & Eng. (Tartt, 1992) [5] & \multicolumn{1}{|c|}{ Ukr. (Tartt, 2017) [6] } \\
\hline 1 & Party Pig & «Кабан-Випиван» \\
\hline 2 & Mr Off-Campиs & 3-Міста-Наӥжджайко \\
\hline 3 & Flipper Leach & Кюветна Ліч \\
\hline
\end{tabular}

The translator's decision may be explained by the necessity to make the lexical meanings of the proper nouns explicit, since they are essential for understanding the immediate context. "Party Pig" drinks alcohol and does socially unacceptable things; " $\mathrm{Mr}$ Off-Campus" is a person who does not live on campus and, thus, is either ignorant or too arrogant to follow the local rules; the etymology of "Flipper Leach" is also explained in the novel: "she flipped over her dad's Volvo". In «Кабан-Випиван» the translator creatively uses sense development instead of word-for-word translation to reproduce the meaning of the nickname and creates the rhyme to preserve the humorous effect: Випиван is a nonceword derived from the verb випивати following the patterns of Ukrainian word formation. 3-Міста-Наӥжджайко has a nonce-word in its structure as well: Наӥжджайко derived from the colloquial verb наӥжджати which has a negative connotation of "uninvited/intrusive" or "arriving in large numbers"; $M r$ is omitted. The proper noun 
Кюветна Ліч combines transcription (Leach - Лiч - is the surname) and sense development: since the girl flipped over in the car, she might have found herself in кювет a road ditch - which turned into an attribute Кюветна. The mentioned nicknames were domesticated by means of colloquial elements that serve as stylistic equivalents and sound natural in the TT.

\subsection{Interjections}

Interjections are means by which we communicate every subtle nuance of our emotions. According to Ameka, interjections may be defined as a subset of items that encode speaker attitudes and communicative intentions and are context-bound. There are primary interjections, that is, they are not used otherwise; and secondary interjections, that is, other words which come to be used as interjections by virtue of their notional semantics [31]. The former are not identical to other words. Often they have non-word-like phonological characteristics, e.g. English Ugh!, Phew!, Mmm!, Ukrainian Oвва! Oй! Гм! which can sometimes be seen as mimetically motivated; for example, the velar or post-velar fricative in $U g h$ ! can be linked with gagging or clearing the throat [32]. As Goddard points out, the distinction between primary and secondary interjections is blurred a little by the existence of modified or sanitised quasi-words, such as, for example, Geez! (from) Jesus!), Cripes! (from Christ!) and Darn! (from Damn!). Moreover, descriptive linguists often use the term interjectional phrase to designate multi-word expressions, such as My God!, Holy shit!, God damn it!.

According to Zarytskyi, there are two main ways of translating interjections depending on the translator's intention. If they want to reproduce the national colouring of the original text, then they can resort to transcription with explanation (foreignisation) [25]. For example, English Ouch! - expressing feeling of sudden pain - can be rendered as "Ayu! він скринув від болю". Another way involves using the corresponding TL unit to reproduce the meaning of the interjection. In this case, English Ouch! can be translated with Ukrainian $O \check{u}$, which is the example of domestication.

Among the analysed 18 interjections from the ST, 13 items can be classified as primary (Hey!, Huh?, Whooo-hoo!) and 5 items - as secondary (Boy!, Goodness!, Jesus!). All the units are domesticated by means of Ukrainian equivalents producing the same stylistic effect:

Table 12. Rendering English interjections by means of Ukrainian equivalents.

\begin{tabular}{|c|c|c|}
\hline & Eng. (Tartt, 1992) [5] & Ukr. (Tartt, 2017) [6] \\
\hline 1 & 'Yep,' said Bunny proudly & - Угу, - гордовито проказав Банні \\
\hline 2 & $\begin{array}{l}\text { 'Naw,' said Mr Hundy, 'didn't see } \\
\text { Willard Scott. }\end{array}$ & $\begin{array}{l}\text { - Нє, - промовив Гандi, - ведучого } \\
\text { шоу вілларда Скотта так } i \text { не } \\
\text { побачив. }\end{array}$ \\
\hline 3 & $\begin{array}{l}\text { 'Whooo-hoo,' } \\
\text { appreciatively. }\end{array}$ & $\begin{array}{l}\text { - Обана! - прокричав якийсь } \\
\text { поціновувач. }\end{array}$ \\
\hline 4 & 'Hey, Pop, 's said the eldest. & -Агов, тату, - гукнув стариий \\
\hline 5 & 'Yeah,' I said. & -Eze $\boldsymbol{~}$ \\
\hline
\end{tabular}

Context plays a very important part in deciphering the interjection's meaning. The same interjection boy in three different situations described in the novel is translated with three different Ukrainian equivalents (Table 13):

Table 13. Different ways of translating the interjection boy.

\begin{tabular}{|l|c|ccc|}
\hline & Eng. (Tartt, 1992) [5] & \multicolumn{4}{c|}{ Ukr. (Tartt, 2017) [6] } \\
\hline 1 & Boy, the four of us had really been & Леле, & ми & четверо \\
\hline
\end{tabular}




\begin{tabular}{|c|l|l|}
\hline & messed up & приперлись \\
\hline 2 & Boy. You don't have a fucking clue. & $\begin{array}{l}\text { Капець, ти ж, блядь, нічого не } \\
\text { розумісш. }\end{array}$ \\
\hline 3 & $\begin{array}{l}\text { 'Boy,' said Bunny, shaking his head. } \\
\text { 'The Golden West.' }\end{array}$ & $\begin{array}{l}\text { Оолоти, - похитав головою Банні, - } \\
\text { Золід. }\end{array}$ \\
\hline
\end{tabular}

The interjection boy is used for expressing a strong reaction, especially admiration or excitement. In the first example Bunny himself can hardly believe how "messed up" his friends and he were. The second situation implies that the speaker is strongly disappointed; the third expresses surprise. The interjection intensifies the emotion prevailing in the given context. The domesticated versions of the English interjections help to render the meaning of the SL units and their stylistic effect within the given context and to make characters sound natural.

\subsection{Stylistically neutral vocabulary}

The biggest group of lexical units which underwent domestication in the Ukrainian translation is stylistically neutral vocabulary ( 84 units). All the lexical units from this category were translated by means of stylistically marked lexical and phraseological units, which makes the stylistic translation transformation of expressivation the main way of domestication of the TT in the category.

The translator uses four types of stylistically marked units to enhance the expressiveness of the TT: (a) general colloquial words - 47 items; (b) colloquial phraseological units -8 items; (c) slang -4 items; (d) lexical units in diminutive and augmentative forms -25 items.

The majority of neutral words from this group were translated by means of general colloquial vocabulary (47 out of 84 ). In 4 cases the translator used slang. These are some examples (Table 14):

Table 14. Stylistically neutral English vocabulary rendered by means of general colloquial Ukrainian vocabulary and slang.

\begin{tabular}{|c|c|c|}
\hline & Eng. (Tartt, 1992) [5] & Ukr. (Tartt, 2017) [6] \\
\hline 1 & I could linger two hours over a coffee. & $\begin{array}{l}\text { Я міг по дві години цмулити філіжанку } \\
\text { кави }\end{array}$ \\
\hline 2 & $\begin{array}{l}\text { His collar was open and his clothes } \\
\text { disordered }\end{array}$ & $\begin{array}{l}\text { Мав розстебнутий комір і сколошканий } \\
\text { одяг }\end{array}$ \\
\hline 3 & $\begin{array}{l}\text { Hugh's children screaming and } \\
\text { throwing potato chips }\end{array}$ & $\begin{array}{l}\text { Діти Г’ю верещать } і \text { жббрляють } \\
\text { картопляні чипси }\end{array}$ \\
\hline 4 & $\begin{array}{l}\text { A friend of mine who used to go here } \\
\text { and who's really tough }\end{array}$ & $\begin{array}{l}\text { Умене є один товариш, ну там } \\
\text { валандається сюди-туди, реально } \\
\text { крутий }\end{array}$ \\
\hline 5 & $\begin{array}{l}\text {...it is even more amazing that I } \\
\text { managed to fall asleep }\end{array}$ & $\begin{array}{l}\text {...ще більи дивне те, щуо я примудрився } \\
\text { заснути }\end{array}$ \\
\hline 6 & $\begin{array}{l}\text { The girls knew more about such } \\
\text { matters... }\end{array}$ & $\begin{array}{l}\text { Дівчата були набагато просунутіші в } \\
\text { цььому плані }\end{array}$ \\
\hline 7 & $\begin{array}{l}\text {...it broke me out in cold sweats and } \\
\text { panic }\end{array}$ & $\begin{array}{l}\text {...мене кидало в холодний піт, ія } \\
\text { постійно «очкував» }\end{array}$ \\
\hline 8 & My lawyer said not to worry & Адвокат сказав, щзоб я не парився \\
\hline
\end{tabular}

Stylistically neutral verbs linger, scream, throw and manage have been replaced by stylistically marked verbs цммллти, верещуати, жбурляти, валандатись, примудритися. The adjective disordered with no stylistic colouring turned into 
сколошканий - a Ukrainian adjective labled "colloquial" [23]. Examples 6-7 from Table 14 show expressivation by means of slang (to know more - бути просунутішими; to panic - "очкувати"; not to worry - не паритися). The Ukrainian sentences with lexical units that underwent expressivation acquire fluency of informal conversation, which is an attribute of a domesticated TT.

Another big group of units (25 out of 84 ) was translated by means of lexical units in diminutive and augmentative forms (Table 15):

Table 15. Stylistically neutral English vocabulary rendered by means of lexical units in diminutive and augmentative forms.

\begin{tabular}{|c|l|l|}
\hline & \multicolumn{1}{|c|}{ Eng. (Tartt, 1992) [5] } & \multicolumn{1}{c|}{ Ukr. (Tartt, 2017) [6] } \\
\hline 1 & a little red-haired girl & однісї маленької рудоволоски \\
\hline 2 & I was tired and a bit drunk & я (...) уже був зморений, п'яненький \\
\hline 3 & little gold hairs were curled & золотисті кучерики \\
\hline 4 & He was tremendous & Здоровило, під сто кг \\
\hline 5 & interesting things & дещь цікавеньке \\
\hline 6 & an old Mustang & старенький «мустанг» \\
\hline 7 & Want a cherry?' & Вищеньку? \\
\hline
\end{tabular}

While in examples 1-3 (Table 15) diminutive suffixes of the Ukrainian words convey the diminutive meaning expressed in the ST by adjectives little and a quantifier $a$ bit and in example 4 the augmentative form здоровило conveys the meaning of the adjective tremendous, in examples 5-7 (Table 15) diminutive forms of the words appeared under the influence of the relaxed and informal tone of the particular context within the framework of the American university discourse.

We assume that the same explanation can be applied concerning the following expressivation of neutral ST vocabulary by means of phraseological units (8 out of 84) shown in Table 16:

Table 16. Stylistically neutral English vocabulary rendered by means of Ukrainian phraseological units.

\begin{tabular}{|c|c|c|}
\hline & Eng. (Tartt, 1992) [5] & Ukr. (Tartt, 2017) [6] \\
\hline 1 & $\begin{array}{l}\text { Now, for some reason, it was Charles } \\
\text { and Camilla who weren't speaking. }\end{array}$ & $\begin{array}{l}\text { Тепер якась кішка пробігла між } \\
\text { Чарльзом і Каміллою. }\end{array}$ \\
\hline 2 & $\begin{array}{l}\text { Though I would've told them } \\
\text { anything if I thought they'd send me } \\
\text { home.' }\end{array}$ & $\begin{array}{l}\text { Хоча я був готовий наговорити їм сім } \\
\text { мішків гречаної вовни, аби вони лиш } \\
\text { відіслали мене додому }\end{array}$ \\
\hline 3 & $\begin{array}{l}\text { My room seemed abandoned and } \\
\text { small, like it had stood empty for } \\
\text { weeks. }\end{array}$ & $\begin{array}{l}\text { Кімната виглядала покинутою та } \\
\text { зімуленою, ніби стояла пусткою кілька } \\
\text { тижнів. }\end{array}$ \\
\hline 4 & $\begin{array}{l}\text { Well, I didn't want to see them, either, } \\
\text { so I headed over to Bram's, and } \\
\text { Charles I guess just went to some } \\
\text { townie bar and got completely } \\
\text { rucked up.' }\end{array}$ & $\begin{array}{l}\text { Ну, я точно не хотів із ними } \\
\text { перестріватися, пому гайнув до Брема, } \\
\text { а Чарльз, по-моєму, пішов оббивати } \\
\text { пороги якихось генделиків, де й упився } \\
\text { як квач. }\end{array}$ \\
\hline
\end{tabular}

The phraseological units кішка пробігла між ними, наговорити сім мішків гречаної вовни, стояти пусткою, оббивати пороги that replace English neutral units not to speak to somebody, to tell anything, to stand empty and to go intensify the informality of the text and bring the characters (including the narrator of the story) closer to the reader. 
According to the results of the analysis, percentage correlation of phraseological and lexical means used for expressivation of 84 stylistically neutral lexical units from the ST looks as follows:

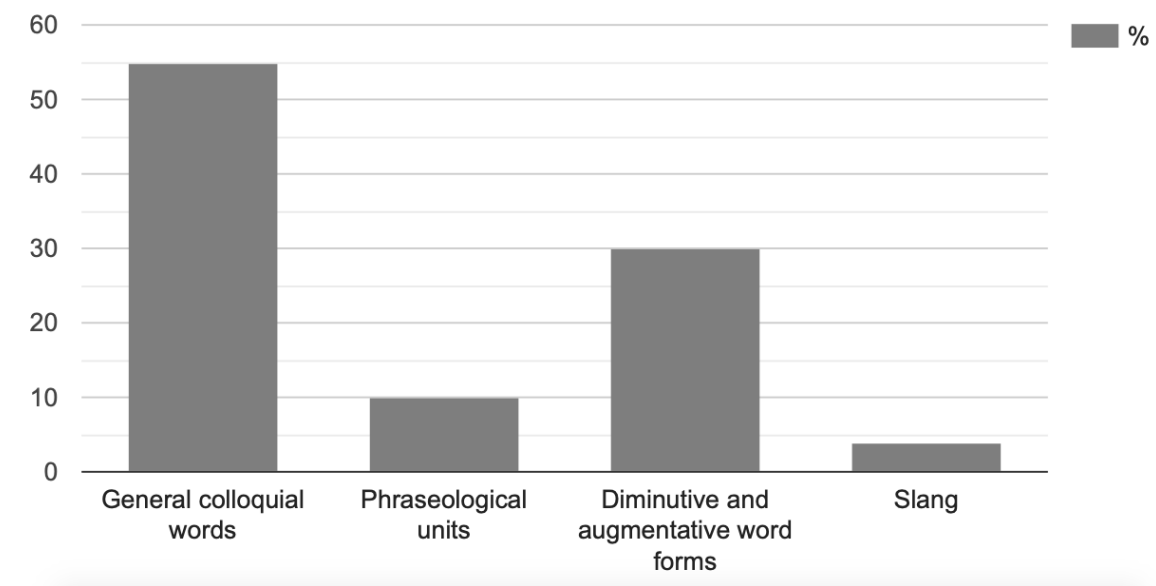

Fig. 3. Percentage correlation of phraseological and lexical means used for expressivation of stylistically neutral lexical units.

To sum it up, due to the analysis of 191 lexical and phraseological units from the ST, the following data were obtained:



Fig. 4. Correlation between ways of translation and domestication strategy.

As seen from the Fig. 4, the prevailing way of domestication strategy implementation in American university discourse is translation by means of stylistic equivalents $(53 \%)$. Predominantly, this method was used for reproducing ST idioms, phrasal verbs, interjection, colloquial vocabulary and domesticated proper nouns. The second big group of units $(44 \%)$ was domesticated by means of stylistic translation transformation of expressivation (applied to stylistically neutral ST vocabulary). Only 3\% of units were rendered by means of stylistic translation transformation of logisation.

\section{Conclusion}

The article is focused on disclosing stylistic aspects of the domestication strategy representation in rendering phraseological and lexical units in American university 
discourse based on the novel The Secret History by Donna Tartt and its Ukrainian translation. A comparative analysis of the original and translated texts was held. Stylistic, contextual and translation analyses were employed. The notion of domestication translation strategy was investigated. The following six groups of phraseological and lexical units in the ST, domesticated in the Ukrainian translation within the framework of American university discourse, were singled out: (1) idioms - 26 units (14\%); (2) phrasal verbs - 21 units (11\%); (3) colloquial vocabulary (slang and vulgarisms) - 39 units (20\%); (4) interjections - 18 units $(9 \%)$; (5) proper nouns - 3 units (2\%); (6) stylistically neutral vocabulary -84 units $(44 \%)$. As seen from the research data, the prevailing way of implementation of domestication strategy in American university discourse is translation by means of stylistic equivalents (53\%). Predominantly, this way of translation was used for reproducing ST idioms, phrasal verbs, interjection, colloquial vocabulary and domesticated proper nouns. The second big group of units (44\%) was domesticated by means of stylistic translation transformation of expressivation (applied to stylistically neutral ST vocabulary). Only $3 \%$ of units were rendered by means of stylistic translation transformation of logisation. Prospects for further scientific research involve establishing the correlation between translation strategies of domestication and foreignisation in American university discourse.

\section{References}

1. L. Venuti, The Translator's Invisibility: A History of Translation (Routledge, London \& New York, 1995)

2. E. Nida, Towards A Science Of Translation (E.J. Brill., Netherlands, 1964)

3. N. D. Arutyunova, Discourse (Sov. Entsik1., Moscow, 1990)

4. I. I. Parulina. Bull. of the South Ural State Univ. Ser. Linguistics, 13 (2), 70-74 (2016) DOI: $10.14529 /$ ling 160213

5. D. Tartt, The Secret History (Penguin Books, London, 1992)

6. D. Tartt, The Secret History (Knyzhkovyi klub "Klub Simeinoho Dozvillia", Kharkiv, 2017)

7. H. P. Krings, Translation problems and translation strategies of advanced German learners of French (Interling. and Intercult. Communication, 1986)

8. W. Loescher, Translation performance, translation process and translation strategies (Guten Narr, Tuebingen, 1991)

9. R. T. Bell, M. Baker (Ed), Routledge encyclopedia of translation studies. (Routledge, London and New York, 1998)

10. M. Shuttleworth, M. Cowie, Dictionary of translation studies (Routledge, London and New York, 1997)

11. V. Vynohradov, V. S. Introduction to the science of translation. (Yzdatelstvo ynstytuta obshcheho sredneho obrazvanyia RAO, Moscow, 2002)

12. V. Komissarov, V. Translation Theory: Linguistic Aspects. (Vysshaya shkola, Moscow, 1990)

13. Ya. Retsker. Theory of translation and translation practice. (R. Valent, Moscow, 2004)

14. E. Nida. Language, Culture and Translating. (Shanghai Foreign Language Education Press, Shanghai, 1993) 
15. P. Newmark. Approaches to Translation. (Shanghai Foreign Language Education Press, Shanghai, 1993)

16. L. Slavova, O. Borysova, N. Gach et al., Translation practice (Logos, Kyiv, 2019)

17. V. I. Karaban, Translation of English scientific and technical literature (Nova Knyha, Vinnytsa, 2001)

18. L. Naumenko, A. Gordyeyeva. Practical Course of Translation from English into Ukrainian (Nova Knyha, Vinnytsa, 2011)

19. K. Womack, B. Shaffer, A Companion to the British and Irish Novel 1945-200, 326339 (2005)

20. A. Edemariam, The Guardian (2004) URL: https://www.theguardian.com/books/2004/oct/02/featuresreviews.guardianreview37

21. V. A. Kukharenko. A Book of Practice in Stylistics (Flinta, Moscow: Flinta, 2010)

22. Longman Dictionary of Contemporary English. URL: https://www.ldoceonline.com

23. Academic explanatory dictionary of the Ukrainian language. URL: http://sum.in.ua

24. A. Makkai, Idiom structure in English. (Mouton \& Co., The Hague, 1972)

25. M. S. Zarytskyi, Translation: Creation and Editing (Parlam. vyd-vo, Kyiv, 2004)

26. Farlex Dictionary of Idioms. URL: https://idioms.thefreedictionary.com

27. O. Vorobyova, Int. Research J. 1 (32-3), $45-48$ (2015) URL: https://researchjournal.org/wp-content/uploads/2015/02/1-3-32.pdf

28. Advanced Learner's Dictionary. URL: https://www. oxfordlearnersdictionaries.com

29. L. Stavytska, Ukrainian language without taboo. Dictionary of profanity and its corresponding words. Obscenisms. Euphemisms. Sexualisms (Krytyka, Kyiv, 2008)

30. B. S. Pour, Trans. J. 13(4) (2009) URL: http://translationjournal.net/journal/50proper.htm

31. F. K. Ameka, J. of Pragmatics, 18(2/3) (1992). DOI: 10.1016/0378-2166(92)90048-G

32. C. Goddard, Yearbook of Corpus Linguistics and Pragmatics, 55-77 (2014) DOI: 10.1007/978-3-319-06007-1_4 